\title{
Analysis of attendance motivation in a Belfast venereal diseases clinic
}

\author{
J. D. H. MAHONY \\ From the Department of Venereology, Royal Victoria Hospital, Belfast
}

The object of this study was three-fold:

(1) To analyse the factors which prompted patients to attend the 'Special Clinic' of the Royal Victoria Hospital, Belfast, and so to determine the relative importance of symptoms in patients of both sexes.

(2) To judge the effect of venereal disease propaganda, health education, and contact-tracing in bringing to the clinic patients in whom symptoms were absent or ignored.

(3) To compare histories from women with gonorrhoea, trichomoniasis, or both infections, to discover the extent to which symptoms prompted attendance, and to judge whether the reasons for attendance would give a valid means of assessing the overall severity of symptoms from each type of infection.

The first two parts of the study included all patients making their first ever appearance at the clinic from the period January 1, 1969, until June 30, 1969. In all there were 702 patients, 446 men and 256 women, giving a male/female ratio of 1.74 to 1 . In the third part of the study, the cases of women with gonorrhoea, trichomoniasis, or both, who were diagnosed during the years 1967, 1968, and the first 6 months of 1969, were included.

Received for publication July 6, 1970

\section{Findings and commentary}

Table I shows that only 23 per cent. of 256 women were prompted to attend because of symptoms suggesting sexually transmitted disease, whereas the corresponding proportion for men was 87 per cent. of 446. Despite the large disparity in the attendance behaviour of the two sexes, there is a virtually identical overall pattern when patients with overt symptoms are considered; 53 per cent. of women (32 of 60) and 54 per cent. of men (214 of 398) consulted another doctor, usually the family practitioner, before attending the clinic. The fact that nearly half the men and women did not attend the clinic directly, despite their symptoms, indicates the need for improved publicity.

Table II (overleaf) shows the behaviour of patients whose clinic attendance was not prompted by symptoms, either because these were absent or because they were of minor degree and thought not to justify a visit to the doctor.

\section{(i) Received contact slip}

No less than 182 (71 per cent.) of the whole group of 256 women attended as the result of being given a contact slip by a man who was already a patient at the clinic. It was revealed that the attendance of only 11 per cent. of source contacts of gonorrhoea

TABLE I Proportion of patients whose attendance was motivated by symptoms, by sex

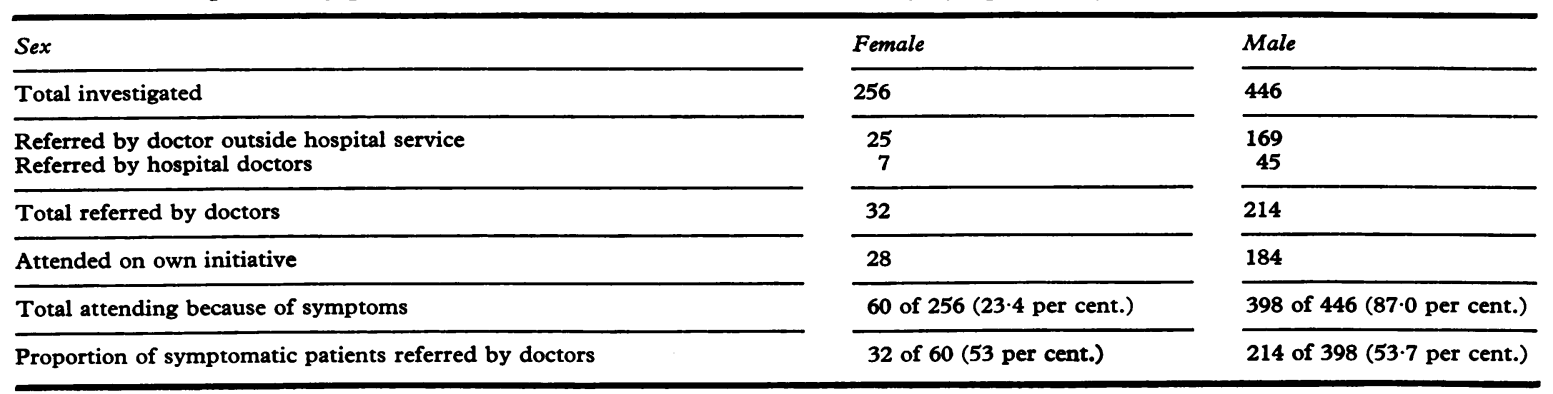


TABLE II Attendance of asymptomatic patients, by sex

\begin{tabular}{|c|c|c|c|}
\hline \multicolumn{2}{|l|}{ Sex } & $\begin{array}{l}\text { Female } \\
182 \text { (71 per cent.) } \\
6 \text { (2.3 per cent.) } \\
4(1.5 \text { per cent.) } \\
3 \\
1 \\
0\end{array}$ & $\begin{array}{l}\text { Male } \\
11 \text { ( } 2.4 \text { per cent. }) \\
0 \\
7 \text { (1.5 per cent. }) \\
3 \\
23 \text { (5.2 per cent.) } \\
4\end{array}$ \\
\hline \multicolumn{2}{|c|}{$\begin{array}{l}\text { Total asymptomatic } \\
\text { Total symptomatic }\end{array}$} & $\begin{array}{r}196 \\
60\end{array}$ & $\begin{array}{r}48 \\
398\end{array}$ \\
\hline \multicolumn{2}{|c|}{ Total cases } & 256 & 446 \\
\hline
\end{tabular}

Figures in parentheses are percentages of whole series.

was secured, though the results with subsequent contacts were very much better. Clearly, this clinic needs to adopt a more vigorous effort in the contacttracing of 'reservoir' cases, though a slightly less dedicated approach than that described by Muspratt and Ponting (1967) would probably be better accepted in a community such as Northern Ireland.

\section{(ii) Referred by doctor outside hospital service}

The doctor concerned was most frequently the general practitioner, but on a few occasions he was a medical officer in the Services or the Merchant Navy. It will be noted that not a single asymptomatic male patient was referred from this source. The most likely explanation for this is that it is rare for asymptomatic men to consult a doctor except for the purpose of collecting a certificate. Only 2.3 per cent. of asymptomatic women were referred by the family doctor. This is possibly explained by the fact that not only the patient but in many instances the doctor may not be fully aware of the fact that sexually transmitted disease in women is so often a silent process in the early stages. One must also bear in mind that some women may be reluctant to tell the family doctor explicitly that they have been 'at risk'. More information directed towards doctors working in other fields seems to be indicated by the above results, and there certainly seems to be a need for improved health education among women.

\section{(iii) Referred by 'hospital' doctor}

Among the eleven patients with minimal symptoms or with no symptoms referred from other hospital departments ( 7 males and 4 females), none of the women had sexually transmitted disease. Two of the men had latent syphilis, one had signs but no symptoms of tabes dorsalis, and two were congenital syphilitics. Two of these cases were referred from the Blood Transfusion Service, indicating that more general use of serological screening in other hospital departments could be effective in detecting undiagnosed syphilitics. (iv) Influenced by current propaganda

The proportion of asymptomatic or 'cryptosymptomatic' patients of either sex influenced to attend as a result of current propaganda was negligible and only one of these, a man with nongonococcal urethritis, was suffering from a sexually transmitted disease. Many venereologists make the point that it is the anxiety-prone rather than the promiscuous section of the public that responds to propaganda from the mass media. One suspects that this is because much of the propaganda may have been produced with the object, unintentional or deliberate, of entertaining, or even horrifying, rather than educating. Fluker (1970) has again made the point that fear is not a deterrent towards promiscuity and may indeed deter patients from seeking medical advice at an early stage.

(v) History of casual exposure (with no symptoms) Only one woman in the asymptomatic group attended solely because she had been 'at risk'. For many years now women have been shown the importance of preventive medicine by attendance at antenatal clinics, family planning clinics, and clinics for cervical cytology screening; and the author's previous experience in general practice has taught him that women tend to be much more health conscious than men. It is therefore surprising that only one woman attended because she had been at risk. One can only conclude that the women in the Province of Ulster are largely unaware of the asymptomatic nature of sexually transmitted disease and that there is an urgent need for suitable education directed towards young women in particular. It will be noted that $5 \cdot 2$ per cent. of the asymptomatic men came to the clinic for a check-up simply because they had been at risk. Although this figure is better than that for women, with the increasing incidence of homosexuality one can expect an increasing incidence of unsuspected disease in the future, and education directed towards both sexes would not be out of place. 
(vi) 'Opportunist' group

This refers to the relatives and occasionally the friends of patients who either accompanied them to the clinic or visited them in the Ward. One striking example was that of a young Dutch seaman who accompanied one of his shipmates with gonorrhoea to this clinic. It was noted that this young man had a lesion on his lip, and this proved on investigation to be a primary chancre.

\section{Attendance motivation of women with gonorrhoea and trichomoniasis}

When investigating the reasons for the attendance of women with gonorrhoea, Trichomonas vaginalis infestation, or combined infection, it was noted that during the first 6 months of 1969 only one out of 39 women with gonorrhoea came to the clinic on account of symptoms, whereas the proportion of those with trichomoniasis was eight out of nineteen (42 per cent.). Surprisingly, the proportion of women with the double infection who attended because of symptoms, namely 20 per cent. ( 3 of 15), was less than half that for women with trichomoniasis alone. To ascertain whether this finding was a chance event due to the small numbers involved, the case records for 1967 and 1968 were studied retrospectively. The totals of cases in each of the three groups are shown in Table III, the numbers in brackets indicating the proportion of women who attended because of symptoms. Essentially the same finding emerged from investigation of the larger number of cases, namely that approximately 35 per cent. of women with trichomoniasis attended because of symptoms whereas, only 20 per cent. of women with the double infection attended for this reason. These differing proportions are statistically significant $(P<0.05)$. Whether the combined infection really does give rise to less marked symptoms than infestation with Trichomonas vaginalis only is open to question, and there may well be this alternative explanation (Willcox 1970), that women with the combined infection may come from a more promiscuous group and possibly be less fastidious about their symptoms. This matter is to be investigated further.

It will be noted from Table III that out of 154 women with trichomoniasis, 71 (46 per cent.) were also infected with gonorrhoea, a finding which agrees with that of Tsao (1969) and is a well recognized phenomenon among the selected female population of the venereal disease clinics. Table III also shows that only two out of 130 women with gonorrhoea had reported to the clinic on account of their symptoms. This, while again demonstrating the relatively asymptomatic nature of gonorrhoea, more importantly indicates the need for intensification of education in these matters directed particularly towards women and girls.

Three suggestions are offered:

(1) That every girl before leaving school should be left in no doubt that women with sexually tranmitted disease may be asymptomatic carriers sometimes for weeks or even months.

(2) That promiscuous women should be encouraged to attend for examination every 3 to 4 months even in the complete absence of symptoms. The report of the Chief Medical Officer (England and Wales) for 1962 stated unequivocally that 'the most promising method of breaking the chain of transmission (of V.D.) is to persuade sexually casual girls and young women to attend clinics regularly for tests, whether they have symptoms or not.

(3) That asymptomatic women, and to a lesser extent men, who have been at risk because of a casual sexual encounter should be persuaded to attend for investigation more frequently than is the case at present.

New V.D. posters designed in conjunction with the Department of Health and Social Services for Northern Ireland will emphasize the asymptomatic nature of V.D. in women.

\section{Summary}

Factors which prompted patients to attend the Venereal Diseases Department of the Royal Victoria

TABLE III Proportion of women with gonorrhoea, trichomoniasis, or both infections, who attended because of symptoms

\begin{tabular}{|c|c|c|c|c|c|c|}
\hline \multirow[t]{3}{*}{ Year } & \multicolumn{6}{|c|}{ Diagnosis } \\
\hline & \multicolumn{2}{|c|}{ Gonorrhoea } & \multicolumn{2}{|c|}{ Trichomoniasis } & \multicolumn{2}{|c|}{ Gonorrhoea and Trichomoniasis } \\
\hline & $\begin{array}{l}\text { No. of } \\
\text { cases }\end{array}$ & $\begin{array}{l}\text { No. attending because of } \\
\text { symptoms }\end{array}$ & $\begin{array}{l}\text { No. of } \\
\text { cases }\end{array}$ & $\begin{array}{l}\text { No. attending because of } \\
\text { symptoms }\end{array}$ & $\begin{array}{l}\text { No. of } \\
\text { cases }\end{array}$ & $\begin{array}{l}\text { No. attending because of } \\
\text { symptoms }\end{array}$ \\
\hline $\begin{array}{l}1967 \\
1968 \\
1969 \\
\text { (1st } 6 \text { mths) }\end{array}$ & $\begin{array}{l}36 \\
55 \\
39\end{array}$ & $\begin{array}{l}0 \\
1 \\
1\end{array}$ & $\begin{array}{l}27 \\
37 \\
19\end{array}$ & $\begin{array}{r}9 \\
12 \\
8\end{array}$ & $\begin{array}{l}20 \\
36 \\
15\end{array}$ & $\begin{array}{l}4 \\
7 \\
3\end{array}$ \\
\hline Total & 130 & 2 & 83 & 29 (35 per cent.) & 71 & 14 (20 per cent.) \\
\hline
\end{tabular}


Hospital, Belfast, were studied to determine the relative importance of symptoms, contact-tracing, and health education. Additionally, the significance of symptoms in women with gonorrhoea and trichomoniasis was explored. The study revealed that only a quarter of the women attended because of symptoms of sexually transmitted disease, compared with 87 per cent. of men. 71 per cent. of women attended because they had received a contact slip. Only two of 130 women with gonorrhoea attended because of symptoms. Weakness of contact-tracing and of health education was revealed, as was the virtually negligible effect of current venereal disease propaganda. Methods of improvement are suggested.

I should like to thank Dr. J. S. McCann for allowing me to review his patients and for making some helpful suggestions, and also Mr. H. Dougan for valuable help in compiling the necessary data.

\section{References}

ChIEF MEdical Officer (1964) 'Annual Report for the Year 1962'. Brit. F. vener. Dis., 40, 55

FLUKER, J. L. (1970) Bull. Inst. Techns Venereol., 1, 17

Muspratt, B., and Ponting, L. I. (1967) Brit. $\mathcal{F}$. vener. Dis., 43, 204
Tsao, W. (1969) Brit. med. F., 1, 642

WILICox, R. R. (1970) Personal communication.

Analyse des motifs amenant les malades à consulter dans une clinique vénéréologique de Belfast

SOMMAIRE

On a étudié les facteurs qui conduisaient les malades à consulter au Département de Vénéréologie du Royal Victoria Hospital, Belfast, pour déterminer parmi ceux-ci l'importance relative des symptômes, de la recherche des contagieux et de l'éducation sanitaire. En outre, on examina la valeur à attribuer aux symptômes chez les femmes atteintes de gonococcie ou de trichomonase. Cette étude a montré qu'un quart seulement des consultantes se présentaient à l'occasion de symptômes de maladie vénérienne alors que le chiffre était de 87 pour cent chez les hommes. 71 pour cent des consultantes se présentèrent après avoir reçu une convocation épidémiologique. Parmi 130 femmes atteintes de gonococcie, 2 seulement consultèrent à cause des symptômes qu'elles avaient ressentis. Cette étude a révélé la faiblesse de la recherche des contaminateurs et de l'éducation sanitaire, aussi bien que l'effet pratiquement négligeable de la propagande antivénérienne courante. On suggère des méthodes pour améliorer cette situation. 